\title{
FAKTOR PENINGKATAN PELAYANAN KESEHATAN
}

\section{Petrus Atong}

\author{
Fakultas Ilmu Sosial dan Ilmu Politik Universitas Kapuas Sintang
}

Jln. Y.C.Oevang Oeray Nomor: 92 Baning Kota Sintang.

Email:atong-petrus@gmail.com

\begin{abstract}
Abstrak: Penelitian tentang Faktor peningkatan pelayanan kesehatan pada Puskesma Sungai Durian Kecamatan Sintang, pelayanan keluarga kesehatan dan faktor-faktor peningkatan pelayanan kesehatan keluarga pada Puskesmas Sungai Durian Kecamatan Sintang. Adapun jumlah subyek dalam penelitian ini adalah beberapa orang dengan rincian sebagai berikut :Tenaga medis yang ada di Puskesma Sungai Durian Kecamatan Sintang. Teknik Pengumpulan Data Wawancara, dan Observasi. Kegunaan penelitian yang diharapkan dari penelitian ini adalah sebagai berikut: Secara Teoritissebagai bahan kontribusi atau masukan akademis dan pengembangan ilmu sosial dibidang Administrasi Negara, khususnya tentang Manajemen Pelayanan Public.Kegunaan Praktis kegunaan penelitian yang diharapkan adalah sebagai sumbangan pemikiran serta usaha-usaha konkrit dan realistis khusus kepada puskesmas kecamatan, pemerintah kecamatan, serta masyarakat dalam rangka menigkatkan pelayanan kesehatahn keluarga.Aspek penelitian: Pelayanan kesehataan keluarga dengan indikator : Program pemberdayaan keluarga,Program kesehatan reproduksi, Program keluarga berencana, Program penguatan kelembagaan dan jaringan KB, dan Advokasi dan KIE. Faktor penghambat dan pendukung pelayanan keluarga berencana di Puskesmas Kecamatan Sungai Durian Sintang Kabupaten Sintang dengan indikator:,Faktor peningkatkan pelayanan keseshatan keluarga. Hasil penelitian faktor peningkatan pelayanan kesehatan keluarga antara faktor sosialisasi arti penting kesehatan keluarga, fasilitas tenaga medis, sarana dan prasarana serta mobiliasi jangkauan wilayah keluarga.
\end{abstract}

\section{Kata Kunci: Peningkatan, Pelayanan, Kesehatan.}

Program Keluarga Berencana (KB) Nasional bertujuan sebagai upaya pengaturan kelahiran untuk meingkatkan kesejahteraan ibu dan anak, kemudian berkembang untuk melembagakan dan membudayakan norma keluarga kecil bahagia dan sejahtera. Program keluarga berencana diharapkan menjadi bagian dari kebutuhan hidup masyarakat. Program Keluarga Berencana Nasional diajukan sebagai upaya untuk meningkatkan kepedulian masyarakat melalui pendewasaan usia kawin, pengaturan kelahiran, pembinaan ketahanan keluarga dan peningkatan kesejahteraan keluarga serta mewujudkan keluarga kecil, bahagia dan sejahtera.Sejak menjadi program nasional, prigram keluarga berencana di Indonesia telah memberikan hasil yang membanggakan. Keberhasilan ini ditandai dengan semakin terwujudnya norma keluarga kecil sebagai bagian dari tata kehidupan masyarakat yang tercermin antara lain semakin meningkatnya angka keluarga berencana, mengecilnya pula rata-rata anak yang dimilki keluarga, menurunnya angka kematian ibu dan anak, serta menurunya angka pertumbuhan penduduk.

Terwujudnya keluarga-keluarga yang berkualitas, yang menjadi visi dari program keluarga berencana. Program keluarga berencana akan membangun sebuah generasi yang suatu bangsa yang maju dimasa depan dan menjadi sumber daya pembangunan yang tangguh dan mandiri, serta mampu berkompetisi dengan bangsabangsa lain didunia khususnya dalam era globalisasi dan persaingan bebas saat ini.Penduduk dan pembangunan mempunyai kaitan yang sangat erat. Ada yang mengatakan bahwa penduduk yang sangat besar penting bagi pembangunan. Penduduk yang besar dan berkualitas akan menjadi aset yang sangat bermanfaat bagi pembangunan. Sebalikya penduduk yang besar akan menjadi beban yang berat bagi pembangunan jika kualitasnya rendah.

Ekstensi program keluarga berencana mempunyai landasan legal yang kuat. Hal ini tidak dapat dipungkiri karena program keluarga berencana mempunyai andil yang besar dalam meningkatkan kesejahteraan keluarga serta mewujudkan keluarga dan penduduk yang berkualitas sebagi sumber daya manusia yang handal dimasa depan, seperti yang diamanatkan dalam Undang Undang Dasar (UUD) 1945 seperti yang tertuang dalam Pembukaan.Kependudukan dan keluarga berencana merupakan masalah jangka panjang yang harus dicermati secara konprenshif, sistematis dan terkoordinasi. Agar eksistensi program dan kelembagaan keluarga 
berencana di derah dapat berjalan sesuai dengan keinginan Pemerintah maka dikeluarkanlah suatu kebijakan oeh Presiden dengan suatu Keputusan Presiden No.103 Tahun 2001, dimana dinyatakan bahwa sebagaian kewenangan keluarga berencana harus diserahkan kepada daerah selambatlambatnya pada akhir Desember 2003. hal ini berarti bahwa pada tahun 2003 akan dilakukan pelimpahan sebagaian kewenangan Pemerintah pusat ke Daerah dan keberadaan program dan kelembagaan yang menangani keluarga berencana akan sepenuhnya tergantung kepada Keputusan Pemerintah Kabupaten.

Kualitas pelayanan harus memenuhi syarat dan prosedur medis teknis yang baku. Klien harus dapat memenuhi cara kerja alat kontrasepsi yang dipakai dan resiko efek samping yang mungkin timbul. Klien harus dengan penuh kesadaran memilih kontrasepsi yang digunakan. Kondisi ini memang sulit dengan adanya syarat yang harus dipenuhi seperti ketersediaan tenaga, sarana dan prasarana pelayanan yang memadai, baik jumlah maupun kualitasnya. Selain itu diperlukan komitmen dan perubahan perilaku petugas pelayanan untuk memberikan pelayanan yang berkualitas.Peningkatan kualitas pelayanan juga berlaku bagi keluarga miskin yang tidak mampu membayar alat dan jasa pelayanan. Untuk itu diperlukan pengembangan mekanisme pelayanan agar keluarga yang mampu mau mandiri. Sedangkan pelayanan gratis hanya untuk keluarga pra sejahtera dan sejahtera I yang tidak mampu, sehingga mengurangi beban pemerintah untuk membiayayi pelayanan yang berkualitas.

Sebagaimana diamanatkan dalam Undang Undang No.10 Tahun 1992 tentang perkembangan kependudukan dan pembangunan keluarga sejahtera. Setiap penduduk mempunyai hak dan kesempatan yang seluas-luasnya berperanserta dalam upaya perkembangan kependudukan dan pembangunan keluarga sejahtera yang dilakuakan baik melalui lembaga swadaya dan organisasi masyarakat, pihak swasta dan perorangan secara sukarela dan mandiri serta sesuai dengan kemampuan masing-masing.

Puskesmas merupakan sarana yang strategis dalam rangka melaksanakan peningkatan cakupan pelayanan KB dan kesehatan.Pembangunan kesehatan sebagai salah satu upaya pembangunan nasional yang diarahkan guna tercapainya kesadaran, kemauan dan kemampuan untuk hidup sehat bagi setiap penduduk dalam mewujudkan derajat kesehatan yang optimal. Upaya untuk mendekatkan pelayanan kesehatan bagi kelompok-kelompok masyarakat sebagian besar yang tinggal di wilayah pedesaan. Pemerintah khususnya Departemen Kesehatan telah menetapkan kebijakan terhadap penempatan tenaga para medis diarahkan untuk mendukung kebijakan nasional dalam bidang kesehatan dan keluarga berencana yaitu usaha menurunkan angka kematian bayi (IMR) dan angka kematian ibu bersalin (MMR) yang relatif masih tinggi terutama daerah pedesaan yang terdapat puskesmas.

Dari pendapat tersebut diatas dapat diambil kesimpulan bahwa yang dimaksud dengan pelayanan adalah suatu kegiatan berupa pertolongan yang diberikan kepada seseoramg. Dalam hal ini pelayanan terutama pelayanan public atau pelayanan kepada masyarakat. Menurut Chitwood (dalam Frederickson, 1997:70) pelayanan dibagi menjadi 3 (tiga) bentuk dasar yang terdiri dari : 1) Pelayanan yang sama bagi semua; 2) Pelayanan yang sama secara profesional bagi semua; 3) Pelayanan yang sama bagi indiviindividu.

Pembangunan Puskesmas dirintis dengan berbagai pertimbangan yang bersifat strategis yaitu untuk memeratakan pelayanan kesehatan. Menurut Departemen Kesehatan RI (1991 : B-1) Pelayanan kesehatan yang diberikan di Puskesmas ialah pelayanan kesehatan yang meliputi :

a) Pelayanan kuratif (mengurangi penderita dengan cara pengobatan)

b) Pelayanan preventif (melakukan upaya pencegahan penyakit)

c) Pelayanan promotif (upaya peningkatan kesehatan)

d) Pelayanan rehabilitatif (usaha pemulihan kesehatan)

Berpedoman pada UU No.32 Tahun 1992 pelayanan kesehatan dasar adalah segala sesuatu tindakan pelayananan kesehatan yang dilakukan oleh tenaga kesehatan bagi semua masyarakat yang bersifat pokok yang sangat dibutuhkan oleh sebagian masyarakat serta mempunyai nilai strategis untuk meningkatkan derajat kesehatan masyarakat. Puskesmas adalah salah satu sarana pelayananan kesehatan yang paling dasar. Puskesmas melayani kunjungan rawat jalan, kunjungan kesehatan dan kunjungan keluarga berencana. 


\section{METODE PENELITIAN}

Medote penelitian yang di dilakukan adalah metode deskriptif kualitatif dengan menggunakan data sekunder dan primer, menggunakan informan kunci pimpinan puskesmas dan subyek penelitian tenaga medis puskesmas. Analisis data yang digunakan adalah analisis deskriftif kualitatif. Dalam penelitian ini menggunakan jenis penelitian deskriptif. Diungkapkan oleh Singarimbun dan Effendi (1989:4) "Bahwa penelitian deskriptif dimaksudkan untuk pengukuran terhadap fenomena sosial tertentu. Lebih lanjut dikemukakan bahwa penelitian menghimpun fakta, tetapi tidak melakukan pengujian hipotesa.Tujuan dari penelitian deskriptif adlah untuk membuat deskripsi atau gambaran secara sistematis, factual dan akurat mengenai fakta, serta hubungan antara fenomena. Pengguna metode ini dipandang lebih mendukung dalam memberi arti dan makna yang berguna dalam menyerap permasalahan yang berkaitan dengan fokus penelitian.

\section{TINJAUAN PUSTAKA}

Dalam suatu implementasi kebijaksanaan tidak terlepas dari proses sebelumnya yaitu formulasi kebijaksanaan. Untuk itu perlu pemahaman kebijaksanaan, seperti yang dikemukankan Carl J. Frederick (dalam Islamy 1977:17) "Serangkaian tindakan yang diusulkan seseorang, kelompok atau pemerintah dalam suatu lingkungan tertentu dengan menunjukan hambatanhambatan dengan kesempatan-kesempatan terhadap pelaksanaan usulan kebijaksanaan tersebut dalam rangka mencapai tujuan tertentu".

Program kesehatan reproduksi tidak semata-mata sebagai masalah kesehatan fisik yang berkaitan dengan alat, system, fungsi dan proses reproduksi namun juga menyangkut aspek psikologis dan sosial, sebagai dampak penyebab dari perubahan fisiologis yang terjadi. Menurut BKKBN bidang formasi keluarga dan alasisa program (2002:36) materi program kesehatan reproduksi remaja meliputi :

a) Pengenalan alat, fungsi, sistem dan proses reproduksi

b) Pengendalian perilaku yang berakibat pada penularan PMS/HIV serta kehamilan yang tidak diinginkan

c) Informasi dasar yang tepat dan akurat mengenai berbagai resiko dari berhubungan seks yang tidak terlindungi/aman

d) Penundaan hubungan seks dengan cara kontrasepsi e) Pengaruh sosial terhadap perilaku seksual

f) Pengembangan keterampilan berkomunikasi

g) Pengembangan model tentang cara perilaku seksual yang bertanggung jawab

Kualitas pelayanan keluarga berencana harus memenuhi syarat dan prosedur medis teknis yang baku. Syarat kualitas pelayanan harus dipenuhi dengan ketersediaan tenaga, sarana dan prasarana pelayanan yang memadai baik jumlah maupun kualitas. Selain itu diperlukan komitmen dan perubahan perilaku petugas pelayanan untuk memberikan pelayanan berkualitas. Peningkatan kualitas pelayanan juga berlaku bagi keluarga miskin yang tidak mampu membayar jasa dan alat pelayanan. Sebagai mana diamanatkan dalam undang undang No.10 Tahun 1992 tentang perkembangan kependudukan dan pembangunan keluarga sejahtera, setiap penduduk mempunyai hak dan kesempatan yang seluas-luasnya untuk berperanserta dalam upaya perkembangan kependudukan dan pengembangan dan pembangunan keluarga sejahtera yang dilakukan baik melalui keluarga swadaya dan organisasi masyarakat. Pihak swasta dan perorangan secara sukarela dan mandiri serta sesuai dengan kemampuan masing-masing. Penguatan kelembagaan dan keluarga berencana berjalan untuk meningkatan cakupan mutu pelakayanan keluarga berencana dan kesehatan reproduksi serta pemberdayaan keluarga dalam rangka meningkatkan keluarga berkualitas.

Faktor penghambat dan pendukung palayanan kesehatan keluarga berencana pada suatu daerah dapat terjadi disebabkan oleh adanya kebijakan yang ditetapkan pemerintah yang tidak dijalankan sesuai dengan ketentuan yang telah ditetapkan atau dengan kata lain pelayanan keluarga berencana tidak dijalankan sesuai dengan ketentuan dikarenakan beberapa hal diantaranya.Salah satu sumberdaya pada puskesmas yang menentukan keberhasilan kinerja/ program pelayanan keluarga berencana adalah tersedianya jumlah tenaga yang cukup dari segi kualitas maupun kuantitas, baik manajemen maupun fungsional (medis dan paramedis).

Menurut Munijaya (1999:44-45) untuk mengetahui keberhasilan pelaksanaan pelayanan kesehatan, dan pelayanan program keluarga berencana pemerintah telah menetapkan idikator keberhasilan pelayanan sektor kesehatan masyarakat meliputi :

a) Derajat kesehatan (lama hidup, kematian, cacat, kesakitan, status, gizi, 
tingkat pendidikan kesehatan, tersedianya air bersih, kebersihan lingkungan, jamban dan kepenuhan sesakan).

b) Upaya kesehatan (tenaga, peralatan, fasilitas, biaya, kebijakan, informasi kesehatan, organisasi dan kegiatan).

c) Perilaku penduduk terhadap kesehatan

d) Pengadaan sumberdaya

e) Potensi organisasi kemasyarakatan

f) Lingkungan

Sedangkan hambatan dalam pelayanan kesehatan oleh Munijaya (1999:98) meliputi bidang ketenagaan dan staf pelaksa serta hambatan geografis. Bidang ketenagaan masalah yang sering dihadapi adalah jumlah tenaga paramedis yang terbatas, kemampuan tenaga yang masih rendah dan kualifikasi staf yang tersedia juga tidak sesuai dengan kebutuhan. Sebaliknya apabila ketenagaan dan staf pelayanan kesehatan tersedia dengan jumlah yang cukup maka akan menjadi faktor pendukung pelayanan kesehatan dan keluarga berencana.Selain masalah ketenagaan yang juga menjadi kendala atau faktor pendukung dan penghambat dalam melaksanakan proses pelayanan kesehatan dan keluarga berencana adalah dana. Dana berupa anggaran yang disediakan guna menunjang pelayanan kesehatan dan keluarga berencana terutama untuk karyawan dan tenaga medis harus cukup terutama untuk anggaran operaional. Dana guna memperluas operaional harus ditunjang dalam Anggaran Pendapatan Belanja Daerah (APBD) dan Anggaran Pendapatan Belanja Negara (APBN).Keterbatasan dana yang tersedia dalam anggaran negara maupun anggaran daerah akan sangat menghambat dalam pelayanan kesehatan dan pelayanan keluarga berencana untuk pelayanan bagi masyarakat. Anggaran sangat menentukan dalam peningkatan pelayanan kesehatan masyarakat, karena dan yang diperlukan untuk alat dan obat-obatan harganya cukup tinggi, untuk itu diprlukan adanya subsidi pada bidang kesehatan.

\section{PEMBAHASAN HASIL PENELTIAN}

\section{Peningkatan Pelayanan Kesehatan}

Program pemberdayaan keluarga berencana bertujuan untuk meningkatan kesejahteraan dan ketahanan keluarga sebagai unit terkecil masyarakat. Hasil pendataan menunjukan masih tingginya jumlah keluarga prasejahtera dan sejahtera I Tabungan Keluarga Sejahtera (Takesra)
Kredit Usaha Keluarga Sejahtera (Kukesra), Kredit Pengembangan Kemitraan Usaha (KPKU) dan kegiatan bina usaha keluarga sejahtera. Kegiatan pemberdayaan keluarga ini ternyata sangat efektif untuk meningkatkan kesadaran keluarga tentang pentingnya perencanaan keluarga dan perlunya memiliki sikap serta perilaku hidup sehat dan mandiri.

Program pemberdayaan keluarga disesuaikan dengan keadaan dan kondisi daerah masing-masing. Di Kecamatan Sintang program pemberdayaan keluarga yang dilakuakan oleh pihak puskesmas adalah dengan melibatkan kantor kecamatan dan PKK kecamatan dengan pembentukan kelompok TOMAS (Tanaman Obat Masyarakat), TOGA (Tanaman Obat Keluarga) dan TODA (Tanaman Obat Daerah) serta mengaktifkan kelompok posyandu dan pilindes disetiap desa yang ada di kecamatan Menukung.

Program pemberdayaan keluarga yang dilakukan umumnya meliputi kegiatan kelompok bina usaha keluarga sejahtera, penimbangan balita, tahapan keluarga sejahtera dan kegiatan kelompok UPPKS keluarga sejahteradan kegiatan kelompok UPPKS peserta KB. Kebijakan umum yang ditetapkan dalam program keluarga berencana adalah usaha untuk mewujudkan keluarga yang berkualitas melalui promosi, perlindungan dan bantuan untuk mewujudkan hak-hak reproduksi, serta melalui upaya peningkatan partisipasi pria dan meningkatkan derajat kesehatan reproduksi remaja serta upaya pemberdayaan keluarga dan peningkatan peran serta masyarakat.

\section{Kesehatan Reproduksi}

Program ini ditujukan untuk meningkatkan pengetahuan, sikap dan perilaku positif remaja tentang kesehatan reproduksi remaja dalam rangka meningkatkan derajat kesehatan reproduksi dan mempersiapkan kehidupan berkeluarga guna mendukung upaya peningkatan kualitas generasi mendatang. Program ini sangat penting karena bernagai data dan informasi hasil penelitianmenunjukan bahwa kuranya pengetahuan dan kesadaran remaja mengenai akibat negatif dari hubungan bebas termasuk resiko terkena PMS dan HIV/AIDS serta infertilasi akibat aborsi dan PMS, dan belum adanya pelayanan komprensif untuk menangani masalah remaja.

Program kesehatan reproduksi tidak sematamata sebagai masalah kesehatan fisik yang berkaitan dengan alat, system, fungsi dan proses reproduksi namun juga menyangkut aspek 
psikologis dan sosial, sebagai dampak penyebab dari perubahan fisiologis yang terjadi. Menurut BKKBN bidang formasi keluarga dan alasisa program (2002:36) materi program kesehatan reproduksi remaja meliputi :

h) Pengenalan alat, fungsi, sistem dan proses reproduksi

i) Pengendalian perilaku yang berakibat pada penularan PMS/HIV serta kehamilan yang tidak diinginkan

j) Informasi dasar yang tepat dan akurat mengenai berbagai resiko dari berhubungan seks yang tidak terlindungi/ aman

k) Penundaan hubungan seks dengan cara kontrasepsi

1) Pengaruh sosial terhadap perilaku seksual

m) Pengembangan keterampilan berkomunikasi

n) Pengembangan model tentang cara perilaku seksual yang bertanggung jawab

Di Puskesmas Sungai Durian Kecamatan Sintang Kabupaten Sintang program kesehatan reproduksi telah dilakukan oleh puskesmas dengan melakukan penyuluhan kepada para remaja putus sekolah demi menigkatkan pengetahuan mereka tentang arti pentingnya kesehatan reproduksi. Pada penyuluhan juga dilakukan penenalan alat-alat kontrasepsi, sistem dan fungsi serta proses reproduksi. Penyuluhan juga memberikan informasi untuk mengendalikan perilaku yang tepat berakibat pada penularan HIV/AIDS dan berbagai macam penyakit kelamin yang mungkin terjadi akibat adanya perilaku seks bebas.

Belum tersedianya dukungan legalitas terhadap penanganan remaja bermasalah, menyebabkan canggungnya sektor pemerintah yang berwenang untu mengembangkan kegiatan konkrit dalam menangani masalah remaja. Oleh sebab itu perlu dikembangkan kerjasama antara BKKBN dan sektor terkait terutama terutama rumah sakit dan puskesmas dalam penanganan masalah kesehatan reproduksi remaja, karena masing-masing pihak mempunyai kelaebihan dan kekurangan, apabila peran serta dan potensi mereka disinergikan akan diperoleh hasil kerja yang optimal.
Program keluarga berencana bertujuan untuk memenuhi permintaan pelyanan keluarga berencana dan kesehatan reproduksi yang berkualitas dalam rangka mengendalikan angka kelahiran yang pada akhirnya akan meningkatkan kualitas penduduk dan keluarga kecil yang berkualitas. Pelaksanaan program keluarga berencana meliputi kegiatan peserta KB aktif yang sebanding dengan jumlah pasangan usia subur, kegiatan peserta KB aktif menurut metode kontrasepsi, kegiatan pasangan usia subur bukan KB Unmet-need (pasangan usia subur yang melakukan kontrasepsi).

Di Kecamatan Sintang dalam upaya pelaksanaan program keluarga berencana selalu dilakuakan penyuluhan mengenai pentingnya menunda usia perkawinan sesuai dengan usia perkawinan yang ditetapkan dalam UU dimana wanita minimal berusia 17 tahun, selaib itu disarankan kepada keluarga dan ibu-ibu rumah tangga untuk dapat mengatur jarak kelahiran. Program keluarga berencana bertujuan umumnya untuk menjadikan sebuah keluarga yang sehat dan berkualitas serta mandiri. Dibarapkan dengan tujuan tersebut masyarakat mampu melaksanakan hidup sehat cukup sandang dan pangan. Kualitas pelayanan keluarga berencana di Menukung yang dilakuakan oleh puskesmas cukup baik meski disadari jika dilihat dari jumlah tenaga medisnya kurang akan tetapi pelayanan selalu diupayakan dengan maksimal. Disadari bahwa alokasi pendanaan untuk kegiatan keluarga berencana terutama untuk keluarga prasejahtera masih sangat minim akan tetapi upaya untuk peningkatan dana dari tahun ke tahun selalu dilakukan oleh pihak kecamatan dengan mengajukan anggaran ke pemerintah Kabupaten Sintang. Kualitas pelayanan keluarga berencana harus memenuhi syarat dan prosedur medis teknis yang baku. Syarat kualitas pelayanan harus dipenuhi dengan ketersediaan tenaga, sarana dan prasarana pelayanan yang memadai baik jumlah maupun kualitas. Selain itu diperlukan komitmen dan perubahan perilaku petugas pelayanan untuk memberikan pelayanan berkualitas. Peningkatan kualitas pelayanan juga berlaku bagi keluarga miskin yang tidak mampu membayar jasa dan alat pelayanan. Untuk itu diperlukan pengembangan mekanisme agar keluarga yang mampu mau mandiri sedangkan pelayanan gratis hanya untuk prasejahtera dan sejahtera I yang tidak mampu sehingga mengurangi beban pemerintah untuk pembiayaan pelayanan yang berkualitas. 


\section{Program Penguatan Kelembagaan}

Program penguatan kelembagaan dan jaringan keluarga berencana dilakuakan melalui kerjasama dengan PKK kecamatan, PPKD dan sub PPKD melalui PUSTU dan POLINDES yang ada dikecamatan Sintang, dalam setiap kegiatan selalu melibatkan petugas PUSTU dan POLINDES. Penguatan kelembagaan dan jaringan keluarga berencana bertujuan untuk meningkatan cakupan mutu pelayanan keluarga berencana dan kesehatan reproduksi serta pemberdayaan keluarga dalam rangka meningkatkan keluarga berkualitas. Penguatan kelembagaan dan jaringan keluarga berencana dikelompokkan dalam tiga program pokok kegiatan Penguatan kelembagaan dan jaringan keluarga berencana diantaranya adalah sebagai berikut :

a. Penguatan kelembagaan merupakan upaya untuk meningkatan kepedulian dan peran serta lembaga masyarakat baik pemerintah maupun swasta serta organisasi kemasyarakatan dalam program KB nasional guna mendukung pengembangan kualitas keluarga.

b. Pemberdayaan institusi masyarakat pedesaan (IMP) yang diarahkan menjadi IMP adalah sebagai wadah aspirasi sekaligus penggerak pembangunan keluarga berkualitas ditingkatkan lini lapangan sehibngga mampu melaksanakan enam peran IMP yaitu kepengurusan, pencatatan, dan pendataan advokasi, KIE dan rujukan, pertemuan, pelayanan kegiatan, upaya kemandirian serta pengembangan manajemen dan dukungan operaional.

c. Reposisi peran PLKB/PKB merupakan salah satu upaya memperkuat lini lapangan dimana PLKB/PKB merupakan petugas BKKBN terdepan sebagai ujung tombak program KB nasional, mereka langsung berhubungan dengan masyarakat diwilayah kerjanya. Tugas PLKB/PKB harus relevan dan mengacu pada misi dan visi program KB nasional yang telah disesuaikan dengan lingkungan strategis.

Dalam upaya menunjang keberhasilan pelaksanaan misi untuk mewujudkan visi yang telah ditentukan, dilakuakan strategi atau pendekatan program. Program keluarga berencana merupakan bagian yang tidak terpisahkan dari program pembangunan lainnya seperti pendidikan, kesehatan, agama, sosial budaya dan ekonomi. Hal ini sejalan dengan hakekat program yang dimaksudkan untuk membangun keluarga sejahtera, maka pelaksanaan harus dilakukan secara terpadu dengan program pembangunan lainnya termasuk dengan program kewenangan daerah.

\section{Advokasi dan Komunikasi Informasi dan Edukasi}

Program dan advokasi keluarga berencana diarahkan pada pembentukan opini dan pejabat. Keputusan untuk memantapkan dan menigkatkan komitmen serta dukungan dalam pelaksanaan program keluarga berencana nasional. Pembentukan opini diharapakan dapat membangun opini bahwa program KB merupakan program penting, setara dengan berbaga program pembangunan lainnya dan bahwa keluarga yang berkualitas adalah merupakan cita-cita dari setiap keluarga yang harus dibangun masing-masing keluarga bersama masyarakat dan pemerintah.

Pembuatan keputusan diharapkan dapat menghasilkan kebijakan publik serta keputusan yang mendukung pelaksanaan program keluarga berencana dan pengembangan keluarga berkualitas sesuai dengan harapan dan kebutuhan masyarakat. Sebagai salah satu bentuk program komunikasi, advokasi keluarga berencana dimaksudkan sebagai suatu bentuk rangkaian komunikasi strategis yang direncanakan secara sistematis dan dilaksanakan dalam kurun waktu tertentu, baik oleh individu maupun kelompok dengan maksud agar pembuatan kebijakan, dapat membuat kebijakan publikyang menguntungkan bagi masyarakat banyak.

Yang terlibat dalam pelayanan dan penguatan kelembagaan advokasi dan KIE adalah tenaga medis di puskesmas, koordinator $\mathrm{KB}$, pelayanan PPKBD dan sub PPKBD serta kecamatan sebagai motifator. KIE dilaksanakan secara terpadu melalui penyuluhan dan pelayanan rutin setiap bulan di posyandu. Petugas-petugas yang terlibat secara langsung paramedis di puskesmas, PLKB, PKK, Kantor Camat, Kepala Desa, PPKBD, dan sub PPKBD.Advokasi dan KIE dilakukan oleh petugas KB,PKK, PPKBD, sub PPKBD, POSTU dan POLINDES, kegiatan dilakukan melalui posyandu dengan memberikan penyuluhan dan pelatihan kader posyandu. Tujuan dilaksanakannya kegiatan ini adalah untuk menigkatkan wawasan dan pengetahuan keluarga serta mewujudkan keluarga kecil sejahtera bahagia dan berkualitas.

Kegiatan Advokasi program keluarga berencana sekaligus juga dimaksudkan untuk memberikan pemecahan dan pemberdayaan kepada masyarakat banyak yang membutuhkan dan menumbuhkan kearifan pada kelompok masyarakat tertentu untuk mendukung terlaksananya kebijakan 
publik tersebut. Sedangkan komunikasi informasi dan edukasi (KIE) adalah suatu program komunikasi yang diarahkan untuk memabangun citra, meningkatan pengetahuan, perhatian, kesdaran, kepercayaan nilai dan merubah sikap serta perilaku baik individu, kelompok atau masyarakat untuk melakukan tindakan nyata dalam rangka membangun atau mewujudkan keluarga berkualitas.

Pengembangan KIE program KB diupayakan sinergi dengan program advokasi dan ditingkatkan kualitasnya untuk lebih menghargai hak-hak asasi manusia melalui pemberian informasi dua sisi dan dua ara yang dilakukan baik melalui berbagai media atau melalui berbagai konseling dan komunikasi tatap muka. Pada saat ini advokasi dan KIE program KB lebih difokuskan pada pendayagunaan berbagai media massa yang memiliki jangkauan yang luas hal ini dimaksudkan untuk memayungi kegiatan advokasi dan KIE yang dilakukan pada tingkat kabupaten/kota sampai di lini lapangan/ keluarga. Khususnya untuk advokasi tingkat kabupaten, lebih diharapakan pada pemebntukan opini dan pembuatan keputusan tingkat kabupaten, yang diharapakan memberi dampak dan tindak lanjtan di tingkat kecamatan sampai ke tingkat desa/ kelurahan.

\section{Faktor Peningkatan Pelayanan Kesehatan}

Faktor penghambat dan pendukung palayanan keluarga berencana pada suatu daerah dapat terjadi disebabkan oleh adanya kebijakan yang ditetapkan pemerintah yang tidak dijalankan sesuai dengan ketentuan yang telah ditetapkan atau dengan kata lain pelayanan keluarga berencana tidak dijalankan sesuai dengan ketentuan dikarenakan beberapa hal diantaranya.

\section{Ketenagaan}

Salah satu sumberdaya pada puskesmas yang menentukan keberhasilan kinerja/program pelayanan keluarga berencana adalah tersedianya jumlah tenaga yang cukup dari segi kualitas maupun kuantitas, baik manajemen maupun fungsional (medis dan paramedis). Menurut Munijaya (1999:44-45) untuk mengetahui keberhasilan pelaksanaan pelayanan kesehatan, dan pelayanan program keluarga berencana pemerintah telah menetapkan idikator keberhasilan pelayanan sektor kesehatan masyarakat meliputi :

a. Derajat kesehatan (lama hidup, kematian, cacat, kesakitan, status, gizi, tingkat pendidikan kesehatan, tersedianya air bersih, kebersihan lingkungan, jamban dan kepenuhan sesakan).

b. Upaya kesehatan (tenaga, peralatan, fasilitas, biaya, kebijakan, informasi kesehatan, organisasi dan kegiatan).

c. Perilaku penduduk terhadap kesehatan

d. Pengadaan sumberdaya

e. Potensi organisasi kemasyarakatan

\section{f. Lingkungan}

Di Puskesmas Sungai Durian Kecamatan Sintang data menunjukan bahwa tenaga medis dan paramedis yang tersedia diKecamatan Sintang sangat minim sekali dimana untuk Kecamatan Sintang yang terdiri dari sembilan desa tetapi hanya terdapat satu dokter yang dibantu emapat orang paramedis sehingga dilihat dari jumlah yang harus memberikan sangat dirasa krang sekali. Pihak kecamatan bersama dengan puskesmas kecamatan setiap tahunnya selalu berupaya pengajuan penambahan tenaga paramedis dan tenaga medis sebagai salah satu langkah untuk mengatasi kurangnya tenaga yang harus memberikan pelayanan kesehatan. Yang menjadi faktor penghambat dalam pelayanan kesehatan di Kecamatan Sintang adalah masalah ketersediaan sarana danprasarana. Sarana dan prasarana yang di miliki puskesmas kecamatan sangat minim sekali, sehingga ini juga menjadi kendala dalam pemberian pelayanan kesehatan kepada masyarakat.

Sedangkan hambatan dalam pelayanan kesehatan oleh Munijaya (1999:98) meliputi bidang ketenagaan dan staf pelaksa serta hambatan geografis. Bidang ketenagaan masalah yang sering dihadapi adalah jumlah tenaga paramedis yang terbatas, kemampuan tenaga yang masih rendah dan kualifikasi staf yang tersedia juga tidak sesuai dengan kebutuhan. Sebaliknya apabila ketenagaan dan staf pelayanan kesehatan tersedia dengan jumlah yang cukup maka akan menjadi faktor pendukung pelayanan kesehatan dan keluarga berencana.

\section{Anggaran}

Selain masalah ketenagaan yang juga menjadi kendala atau faktor pendukung dan penghambat dalam melaksanakan proses pelayanan kesehatan dan keluarga berencana adalah dana. Dana berupa anggaran yang disediakan guna menunjang pelayanan kesehatan dan keluarga berencana terutama untuk karyawan dan tenaga medis harus 
cukup terutama untuk anggaran operaional. Dana guna memperluas operaional harus ditunjang dalam Anggaran Pendapatan Belanja Daerah (APBD) dan Anggaran Pendapatan Belanja Negara (APBN).Keterbatasan dana yang tersedia dalam anggaran negara maupun anggaran daerah akan sangat menghambat dalam pelayanan kesehatan dan pelayanan keluarga berencana untuk pelayanan bagi masyarakat. Anggaran sangat menentukan dalam peningkatan pelayanan kesehatan masyarakat, karena dan yang diperlukan untuk alat dan obatobatan harganya cukup tinggi, untuk itu diprlukan adanya subsidi pada bidang kesehatan.

\section{KESIMPULAN DAN SARAN}

Berdasarkan pada pembahasan masalah dan analisis data pada bab-bab terdahulu maka penulis merangkum dan menguraikan hasil penelitian ini dalam beberapa kesimpulan. Faktor peningkatan Pelayanan keluarga berencana di Puskesmas Sungai Durian Kecamatan Sintang Kabupaten Sintang yang dilakukan melalui program pemberdayaan keluarga bertujuan untuk meningkatkan kesejahteraan keluarga sebagai unit terkecil dalam masyarakat dilakukan dengan membentuk UPPKS. Untuk program kesehatan reproduksi yang bertujuan meningkatkan pengetahuan sikap dan perilaku positif remaja tentang kesehatan reproduksi remaja dalam rangka meningkatkan derajat kesehatan reproduksi di Kecamatan Sintang secara rutin dilakukan penyuluhan terutama remaja putus sekolah dan ibuibu usia muda.. Kegiatan program keluarga berencana bertujuan untuk memenuhi permintaan pelayanan keluarga berencana dan kesehatan reproduksi yang berkualitas dalam rangka mengendalikan angka kelahiran, yang pada akhirnya akan meningkatkan kualitas penduduk dan mewujudkan keluarga kecil berkualitas. Faktor penghambat dan pendukung pelayanan keluarga berencana pada suatu daerah dapat terjadi disebabkan beberapa hal diantaranya : ketenagaan sangat menentukan keberhasilan kinerja/program pelayanan keluarga berencana. Tersedianya tenaga yang cukup dari segi kualitas maupun kuantitas, baik manajemen maupun fungsional (medis dan paramedis).

Kesimpulan yang dikemukakan diatas maka pada akhir tulisan ini penulis mencoba memberikan sumbangan pemikiran dalam bentuk saran-saran. Adapun saran-saran tersebut adalah sebagai berikut: hendaknya Puskesmas di Kecamatan Sungai Durian Kecamatan Sintang dapat meningkatkan pelayanan keluarga berencana yang dilakukan melalui program pemberdayaan
keluarga.Peningkatan pelayanan kesehatan yang menjadi faktor penghambat dalam pelayanan Keluarga Berencana di Puskesmas Sungai Durian Kecamatan Sintang Kabupaten Sintang hendaknya untuk dihilangkan, Selain itu anggaran Puskesmas berupa dana bentuk anggaran yang disediakan guna menunjang pelayanan kesehatan dan keluarga berencana terutama untuk karyawan atau tenaga medis harus cukup terutama untuk anggaran operasional. Dana guna memperluas operasional harus ditunjang anggaran Pendapatan Belanja Daerah (APBD) dan Anggaran Pendapatan Belanja Negara (APBN).

\section{DAFTAR PUSTAKA}

Azwar. A.H, 1996. Menjaga Mutu Pelayanan Kesehatan, Jakarta : CV. Muliasari

Frederickson, G.H. 1994. Administrasi Ilmu Baru. Jakarta : LP3ES

Islamy, I 1997. Prinsip-prinsip Kebijaksaan Negara. Jakarta : Bumi Aksara

Poerwadarminta. 1976. Kamus Besar Bahasa Indonesia. Jakarta : Balai Pustaka

Keputusan Bupati Melawi No.191 Tahun 2005 Tentang Pembentukan Forum

Komunikasi/Konsultasi Peserta Jaminan Pemeliharaan Kesehatan Masyarakat Miskin dan Peserta Wajib PT. Asuransi KesehatanKabupaten Sintang.

Keputusan Presiden No. 103 Tahun 2001 Tentang Penyelenggaraan Kewenangan Kepada Daerah dari BKKBN Kepada Pemerintah Daerah.

Koertaraningrat. 1985. Metode-Metode Penelitian Masyarakat. Jakarta : PT. Gramedia Pustaka Utama.

Munijaya. 1999. Manajemen Kesehatan. Jakarta : EGC.

Singarimbun, M. Dan Effendi. S. 1989. Metodologi Penelitian Survey. Jakarta : LP3ES.

Tjokromidjojo. 1991. Pengantar Administrasi Pembangunan. Jakarta : LP3ES.

UNKA. 1994. Pedoman Penulisan Skripsi. Sintang : Universitas Kapuas.

Undang Undang No.10 Tahun 1992. Tentang Perkembangan Kependudukan dan Pembangunan Keluarga Sejahtera.

Undang Undang No.25 Tahun 2000 tentang Program Pembangunan Nasional.

Undang Undang No.32 Tahun 1992 tentang Pelayanan Kesehatan Dasar.

Wahab, S.A. 1997. Analisa Kebijaksaan. Bumi Aksara : Jakarta. 